\title{
Strategies which ensure our patient's safety
}

\author{
G Guillaumet*, MJ Marmol, M Sola, S Guzman, L Cuenca, V Segura \\ From ESICM LIVES 2015 \\ Berlin, Germany. 3-7 October 2015
}

\section{Introduction}

In 2007 Althaia carried out a project which consisted in implementing the role of the Referent Nurse. Thus, the motivation in the sanitary professional increased and the patient care improved, which brought with it the creation of a safety team in order to ensure the patients' safety. According to the Spanish Nurse Ethical Code, article 14-15 under chapter 3, all human beings are entitled to the right to life, to their safety and to the protection of their health. The nurse has the obligation to ensure and look after the patients' safety.

In our service we saw the need to set up a standardised way of monitoring procedures, records and nursing protocols.

\section{Objectives}

To improve our patients' health.To guarantee a good implementation of healing/nursing protocols.

\section{Methods}

Creation of a ICU safety team.Monthly meetings with the safety team.Controls of observation, intervention and records during a week every six months.Monitoring of risk indicators, effectiveness and continuity care: pain, pressure sores, check-list of aided intra-hospital transport of patients, medication errors and patient identification.

\section{Results}

Pain: the patients showed EVE $<3$ in $94,4 \%$ of cases.

During the observation period there was a $1,76 \%$ of pressure sores $91 \%$ of internal ICU transfers check-list was fulfilledMistakes when prescribing treatments: 9.4\% $95.5 \%$ of the patients were wearing an ID wristband.

\section{Conclusions}

The creation of a safety team in ICU helps us to achieve our set goals. It also helps us to recognise flaws and/or

Althaia Xarxa Assistencial de Manresa, Manresa, Spain improvements in our job, which has an effect on the patient's safety.

Published: 1 October 2015

doi:10.1186/2197-425X-3-S1-A76

Cite this article as: Guillaumet et al: Strategies which ensure our patient's safety. Intensive Care Medicine Experimental 2015 3(Suppl 1):A76.
Submit your manuscript to a SpringerOpen ${ }^{\circ}$ journal and benefit from:

- Convenient online submission

- Rigorous peer review

- Immediate publication on acceptance

- Open access: articles freely available online

- High visibility within the field

- Retaining the copyright to your article

Submit your next manuscript at $>$ springeropen.com

\section{SpringerOpen ${ }^{\odot}$}

(c) 2015 Guillaumet et al.; This is an Open Access article distributed under the terms of the Creative Commons Attribution License (http://creativecommons.org/licenses/by/4.0), which permits unrestricted use, distribution, and reproduction in any medium, provided the original work is properly cited. 